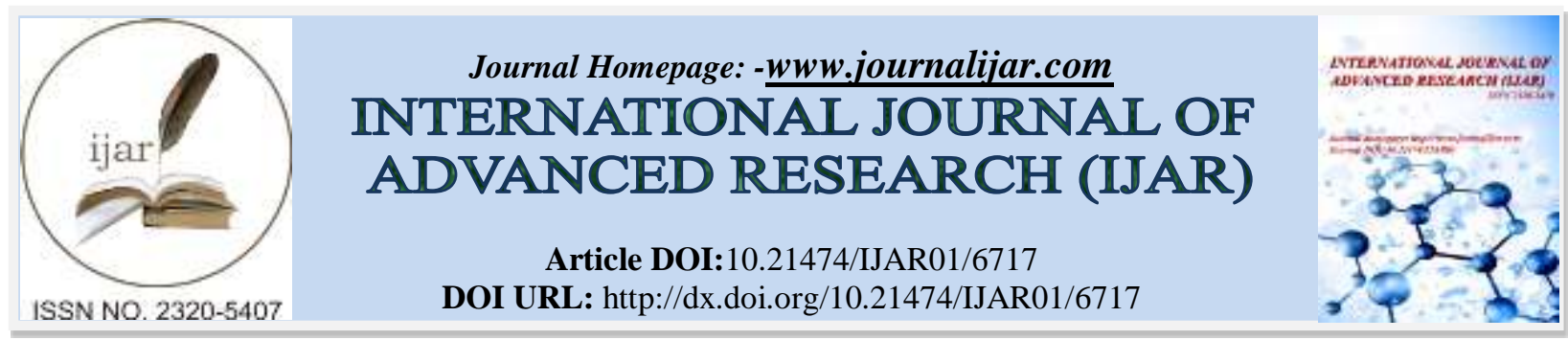

RESEARCH ARTICLE

\title{
ETHNOBOTANICAL STUDIES ON DIFFERENT SPECIES OF BERGENIA IN HIMACHAL PRADESH, INDIA.
}

Dhiraj S. Rawat ${ }^{1}$ and Anjna D. Kharwal ${ }^{2}$.

1. Department of Botany, Govt. Degree College- Dharamshala (Kangra).

2. Department of Botany, Govt. Degree College- Nagrota Bagwan (Kangra).

\section{Manuscript Info}

Manuscript History

Received: 10 January 2018

Final Accepted: 12 February 2018

Published: March 2018

Keywords:-

Indigenous, Himalayas, Traditional

knowledge, Ethnobotanical.

\begin{abstract}
Indigenous practices provided invaluable knowledge and aided in making best use of natural resources as it was dynamic in dissemination and scientific in indigenous experimentation. Bergenia in world, represented by 10 species are widely distributed in Himalayas. The paper deals with the ethnobotanical value of two species along with their distribution in different districts of Himachal Pradesh (H.P.), recorded through interviewing rural populace of the region. The paper had also taken into account the perception of local people about the effectiveness of plants for medicinal and other uses. The work aimed at the preservation of this depleting traditional knowledge.
\end{abstract}

Copy Right, IJAR, 2018,. All rights reserved.

\section{Introduction:-}

The term ethnobotany was coined by J.W. Harshberger in 1895 to "the study of plants used by primitive and aboriginal people" (Anonymous, 1895). Since then, the subject has been variously defined and interpreted by different workers as its discipline began to follow multidisciplinary approach combining a diversity of knowledge bases and methods through the use of anthropological methods (Robbins et al., 1916; Schultes \& Reis, 1995). Plants are the basis of life on earth and are central to people's livelihood. Glimpses of our knowledge in ethnomedicine are available to vedic text (Jain, 1987). Undeniably, there is an inextricable link between indigenous culture and biodiversity as areas of high biodiversity are often found on indigenous community's lands and in their water bodies (Alcorn, 1996). The $15^{\text {th }}$ session of the General Assembly of IUCN held in Christchurch, New Zealand, in October 1991, recognized the importance of the cultural heritage of mankind and the role of traditional cultures in conservation of nature (McNeely \& Pit, 1985). Agenda 21 of the Rio Earth Summit (1992) stated that indigenous people have a vital role in environmental management and development because of their knowledge and traditional practices. Ethnobotanical information in the form of folklore is passed through generations in certain restricted and remote habitations (Chauhan, 1999; Choudhary et al., 2008; Ganesan, 2008; Saini, 1996).

Stretching in an area over 55,673 sq. km (10.54\% of the Himalayan landmass), the state of Himachal Pradesh lies between $30^{\circ}-22^{\prime}-40^{\prime}$ ' and $33^{\circ}-12^{\prime} 20^{\prime \prime}$ north latitudes and $75^{\circ}-45^{\prime}-55^{\prime \prime}$ and $79^{\circ}-04^{\prime}-20^{\prime \prime}$ east longitudes. Phytogeography of the state is characterized with hilly terrain, valleys, splendid mountain ranges and snow clad peaks with elevation ranging from $350 \mathrm{~m}$ in the foothills to $6,975 \mathrm{~m}$ in the high hills. It has twelve districts, viz., Bilaspur, Chamba, Hamirpur, Kangra, Kinnaur, Kullu, Lahaul-Spiti, Mandi, Shimla, Sirmaur, Solan and Una, each having its own culture and traditions. A number of diverse ethnic communities such as Gaddies, Gujjars, Kinnaurs or Kanaurs, Jads, Lahoulis, Spitians, Pangwals and Swangalas with distinct differences in socio-economic and 
socio-cultural conditions inhabit the region. The place is endowed with rich temperate and sub-tropical flora (Balokhra, 2002).

Bergenia (Elephant-eared saxifrage, Elephant's ears) is a genus native to central Asia and common in Himalayas. It belongs to Order Saxifragales and family Saxifragaceae with glossy green coloured leaves which turns red or bronze in cooler regions. It is known as Elephant's ears due to the shape of leaves. The creator of the genus was Conrad Moench who named it in honour of Karl August Von Bergen (Botanist and physician) in 1794.

\section{Methodology:-}

Intensive ethnobotanical exploration were undertaken in some of the rural pockets of Shimla, Kullu, Kangra, Chamba and Mandi districts of Himachal Pradesh in the regions above 2,000m heights. The field tours were planned in such a way so as to collect the ethnobotanically interesting species either in flowering or fruiting stage. Herbarium of collected plants was prepared following Jain \& Rao, 1978. For a better understanding of local beliefs, habits and uses of plants, different categories of people like family heads, healers, old experienced and knowledgeable informants, especially old ladies were repeatedly interviewed. Specific questions based upon Proforma designed by Jain \& Rao, 1978 were asked and the resultant information was recorded in the ethnobotanical field notebook along with the name of locality and local name. Botanical identification of the selected species was first done with the help of regional floras (Chauhan, 1999; Chowdhery \& Wadhwa , 1984; Dhiman, 1976; Hooker, 1897).

For more information three basic approaches were adopted following Phondani et al., 2010:

1. An interview based approach- Questions from informants mainly from old experienced people as they are more aware of the uses of plants.

2. An inventory based approach- An inventory based approach is followed on following questions:

$>$ Whether whole plant or plant parts are used?

$>$ The season of flowering and fruiting

$>$ Whether the plant is used for one disease or for more than one disease?

3. An interactive discussions approach with communities-

$>$ How to use plants?

$>$ Are they used singly or in combination?

\section{Observations:-}

The survey yielded the ethnobotanical information on two species of Bergenia distributed in different parts.

Bergenia ciliata (Haw.) Sternb.

Family: Saxifragaceae.

Locally known as "Sapotri". Herbs with stout creeping rootstocks. Leaves are ovate, red in autumn, margins fringed. Flowers are pink or purple in dense clusters on leafless stem. Fruit is a capsule with many seeds. Seeds are elongated and smooth. It mostly occurs in forests and rock edges with flowering and fruiting in March to July.

Folk Uses:- Flowers pickled and also used in preparation of 'Pakoras'.

Leaves juice and root extract is used for making herbal tea. Root decoction is used for body pain after childbirth, cough, cold, weakness (vet.), wounds, dysentery, kidney and bladder stones; leaf and root extract used as an antiamoebic, anticancer, astringent, carminative, diuretic, fever, hypotensive, spasmolytic, tonic and mostly it is reported above $1,900 \mathrm{~m}$ in present study.

Similar information has also been reported by: (Arora \& Pandey, 1996; Bennet et al., 1991; Chauhan, 1999; Lal et al., 1996; Rana et al., 1996; Roy et al., 1998; Sarin, 1990; Sood et al., 2001, 2012). 


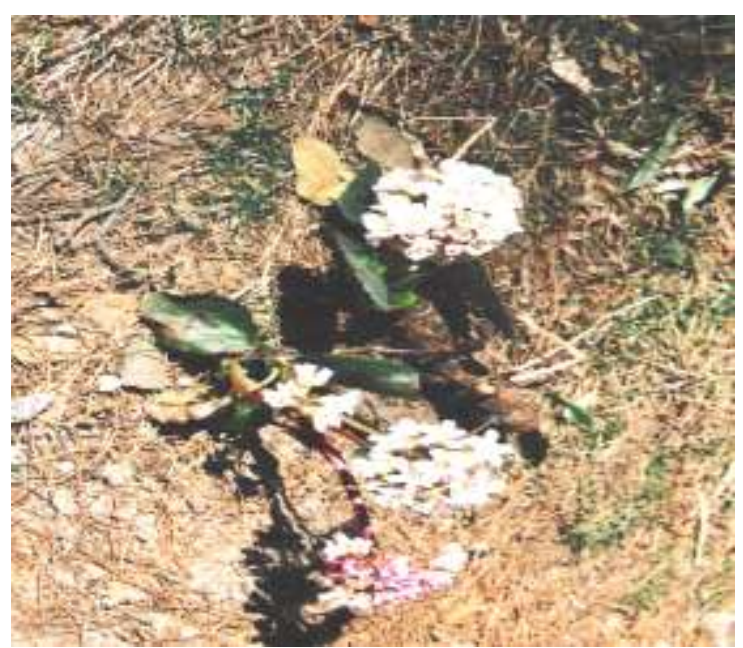

Fig. 1:-Bergenia ciliata (Haw.) Sternb.

Bergenia stracheyi (Hook. f. Thoms.) Engl.

Syn.: Saxifraga stracheyi Hook \& Thomas; S. ciliata Lindl.

Family: Saxifragaceae.

Locally known as "Shilpada".An evergreen, drooping, perennial plant upto30 cm. Rootstock is dark brown. Basal leaves are large, rounded, orbicular, toothed with bristle like hair. Leaf stalks are very short. Calyx is hairy. Flowers are pinkish borne in a cluster of corymbose cyme in a stout leafless stem. Fruits are Capsules with conical minute seeds. It mostly occurs in forests and rock edges with flowering and fruiting in June to August and mostly it is reported above $2,600 \mathrm{~m}$ in present study.

Folk Uses:- Roots used as a substitute for tea. Decoction of roots used as a carminative, antiscorbutic, diuretic, substitute for tea, febrifuge; root extract used for boils, blisters, cough-cold, eye diseases, joint pain, kidney and bladder stones, lung diseases, menorrhagia, opthalmia, stomach complaints, swellings, sores, and toothache. Similar information has also been reported by: (Arora \& Pandey, 1996; Bennet et al., 1991; Chauhan, 1999; Lal et al., 1996; Rana et al., 1996; Roy et al., 1998; Sarin, 1990; Sood et al., 2001, 2012).

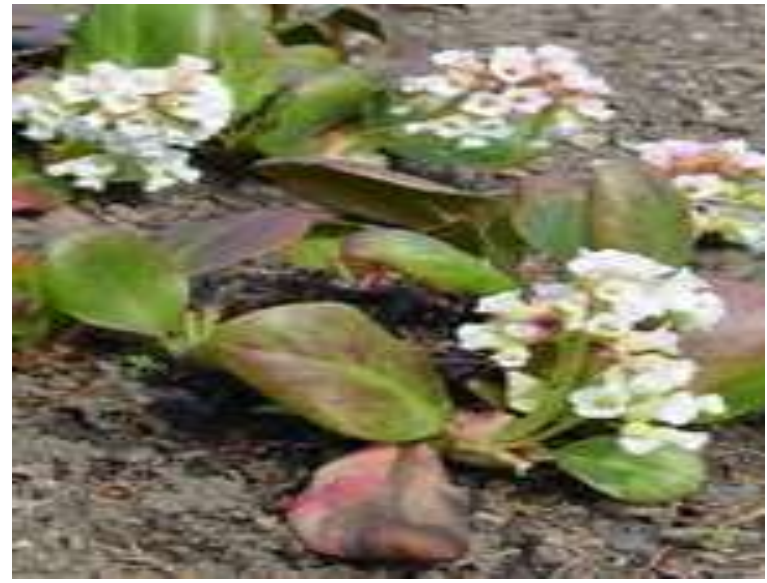

Fig. 2:-Bergenia stracheyi (Hook. f. Thoms.) Engl.

\section{Discussion:-}

2 species, out of 10 found are recorded in Himachal Pradesh (H.P.), which have been found useful to the local rural populace of the Himalayan region. All the species with their vernacular names among the different communities, other regional names along their distribution in some districts of H.P. are described. Out of reported two species, Bergenia ciliata is common while the other B. stracheyiis not common. Bergenia ciliata is edible. As for as 
medicinal value is concerned all the species are highly medicinal and are used singly as well as in combination. The different species are used for more than one disease.

\section{Acknowledgements:-}

The authors are thankful to the local rural populace of Himachal Pradesh (H.P.).

\section{References:-}

1. Alcorn, J. B. (1996): Is biodiversity conserved by indigenous people? In: Ethnobiology in Human Welfare., SK Jain (ed.), Deep Publ., New Delhi, 233-238.

2. Anonymous (1895): Some new ideas, The plants cultivated by aboriginal people and how used in primitive commerce. The Daily Evening Telegraph, Philadelphia, vol. 64, no 134.

3. Arora, R.K. and Pandey, A. (1996): Wild Edible Plants of India- Diversity, Conservation and Use. NBPGR, New Delhi.

4. Balokhra J. M. (2002): The Wonderland Himachal Pradesh. H.G. Publication, New Dehli.

5. Bennet, S.S.R., Biswas, S., Chandra, V., Singh, P.J., Chandra, S. and Dayal, R. (1991): Food from Forests. Indian Council of Forestry Research and Education, Dehradun, India.

6. Chauhan N. S. (1999): Medicinal and Aromatic Plants of Himachal Pradesh. Indus Publ. Co., New Delhi,..

7. Choudhary, K, Singh, M and Pillai ,U (2008): Ethnobotanical survey of Rajasthan - An uptade. Am-Eurasian J. Bot., 1(2) 38-45.

8. Chowdhery, H. J. \& Wadhwa B. M. (1984): Flora of Himachal Pradesh.Vol. 1-3. Bot. Surv. India, Calcutta.

9. Dhiman, D. R. (1976): Himachal Pradesh Ki Vanoshdhiya Sampada. Imperial Printing Press, Dharamsala, H.P.

10. Ganesan ,S. (2008):Traditional oral care medicinal plants survey of Tamil Nadu. Natural Product Radiance, 7: 166-172.

11. Hooker, J. D. (1872-1897): The Flora of British India. Vol. I-VIII, Lalit Mohan Basu, Allahabad.

12. Jain, S .K. and Rao R. R. (1977). A Handbook of Field and Harbarium Methods. Today's \& Tomorrow's Printers \& Publ., New Delhi.

13. Jain, S. K.(1987): A Manual of Ethnobotany. Sci. Publ., Jodhpur.

14. Lal, B., Vats, S.K. Singh, R.D. \& Gupta, A. K. (1996): Plants used as ethnomedicine and supplementary food by Gaddis of Himachal Pradesh, India: 384-387. In: Jain, S.K. (ed.) Ethnobiology in Human Welfare. Deep Publ., New Delhi.

15. McNeely, J.A. and Pit. D (1985) (eds): Culture and Conservation, The Human Dimension in Environmental Planning. Croom Helm, London, New York, Sydney.

16. Phondani, P. C., Maiknuri, R K., Rawat, L. S., Farooquee, N. A., Kala, C. P.,Vishwakarma, S. C. R., Rao, K. S. and Saxena, K. G. (2010): Ethnobotanical uses of plants among the Bhotiyal tribal communities of Niti valley in Central Himalaya, India, Ethnobot. Res. \& Application 18 , 233-244.

17. Rana, J.C., Sharma, B.D., Sood, S.K., and Lakhanpal, T.N. (2005): Genetic Diversity of Himalaya. Publication No.7. Inst. Int. Himalayan Studies, H.P.U., Shimla (H.P.).

18. Robbins, W.W, Herrin J. P. and Freire-Marreco B. (1916): Ethnobotany of the Tewa Indians, Bureau of American Ethnology. Bulletin, no 55. Smithsonian Institutions, Washington, D.C.,

19. Roy, B., Halder, A.C. and Pal, D.C. (1998): Plants For Human Consumption in India. Bot. Surv. India, Calcutta.

20. Saini, V. K. (1996): Plants in the Welfare of Tribal Women and Children in Certain Areas of Central India In: Ethnobiology in Human Welfare, SK Jain (ed.), Deep. Publ., New Delhi, 140-144.

21. Sarin, Y.K. (1990): Some less known but effective folk remedies in North - West Himalayan region. Ethnobotany 2: 39-43.

22. Schultes, R. E. and Reis S. V. (1995): Ethnobotany - Evolution of a Discipline. Chapman, London.

23. Sood, S. K., Rawat, D., Rawat, S. and Kumar, S. (2012): A Handbook of Wild Edible Plants. Pointer publishers, Jaipur.

24. Sood, S.K., Nath, R., and Kalia, D.C. (2001): Ethnobotany of Cold Desert Tribes of Lahaul-Spiti (N.W. Himalaya). Deep Publ., New Delhi. 